\title{
Exploring the Science of Marma - An Ancient Healing Technique - Part 3: Marma in Yoga and Other Ancient Indian Traditions
}

\author{
Alka Mishra*, Vandana Shrivastava \\ Department of Ayurveda and Holistic Health, Dev Sanskriti Vishwavidyalaya, \\ Gayatrikunj-Shantikunj, Haridwar, Uttarakhand, India
}

*Corresponding Author: Alka Mishra - Email: alka.mishra@dsvv.ac.in

\section{License information for readers:}

This paper is published online under the Creative Commons Attribution (CC BY 4.0) License, whose full terms may be seen at https://creativecommons.org/licenses/by/4.0/

Uploaded online: 27 June 2020

\begin{abstract}
Marma Science is an extremely important branch of Ayurveda. Marma points are important vital places in the body, that are the 'seats of life' (Prana - the vital life force). As any injury to these parts may lead to severe pain, disability, loss of function, loss of sensation, or death, therefore, they hold an important place in the science of surgery, wherein they are considered 'Shalya Vishayardha' (half of the entire science of surgery). The ancient scriptures have strictly directed against causing any injury to these vital spots. However, recent researches have attempted the stimulation of Marma points for theraputic benefits, with encouraging outcomes. In view of these mutually conflicting, importance applications of Marma Science, the present study was undertaken for its in-depth study.

Part-1 of this study presented the information about different aspects of Marma Science in various ancient / classical Indian scriptures. Part-2 gave a detailed description of the number of marmas, their location, structures involved, classification, effect of trauma, etc., as per classical texts, as well as correlation with modern science.

The present article, which is part-3 of this study, explores the use of Marma Science in Yoga and other ancient Indian traditions. It is observed that various Yogic practices had been devised with the primary aim of stimulating specific Marma points, with important healing applications. Several ancient Indian traditions used Marma Science both as a martial art for self defense and inflicting injury on the opponents, and as a therapeutic technique for healing purposes.
\end{abstract}

Keywords: Ayurveda, Marma Science, Ashtanga Yoga, Chakras, Kalaripayat, Varma-kalai, Siddha Medicine, Marma Therapy 


\section{Introduction}

Marma Science is an extremely important branch of Ayurveda [1,2]. Marma points are important vital places in the body, that are the 'seats of life' (Prana) (Ashtanga Hridaya Sharira Sthana 4/2) [2] (Prana is the vital life force that governs all the physical and subtle processes of a living being [3-6]). As any injury to these parts may lead to severe pain, disability, loss of function, loss of sensation, or death [7], therefore, they hold an important place in the science of surgery, wherein they are considered 'Shalya Vishayardha' (half of the entire science of surgery) (Sushruta Samhita Sharira Sthana 6/35) [1]. Acharya Sushruta states that Marma sthan, a very vital point, should not be injured and should be kept intact even while doing surgeries (Sushruta Samhita Sharira Sthana 6/21) [1].

However, recent researches indicate that if any Marma point is inflamed or painful, then stimulating its nearby Marma points can help in alleviating this pain [8]. Several studies and texts have reported the therapeutic benefits of Marma Therapy in treating various physical and mental disorders [7-27].

Looking at the importance of the Marma Science with regards to surgeries, as well as their recent use and future possibilities as an effective therapeutic procedure, the present study has been undertaken for an in-depth study of the Science of Marma.

An account of various ancient / classical Indian scriptures, including the Vedas, Upanishads, Puranas, Samhitas, etc., that mention different aspects of the Science of Marma [1,7-15,26-42], was given in Part-1 of this study [43]. Part-2 of this study [44], gave the definition and a detailed description of the properties of Marmas, as stated in the classical texts, mostly written during Samhita kala. The description included information about the number of marmas, their location, structures involved, correlation with Panchamahabhutas, classification, as well as a detailed explanation of marmaghata or viddha lakshanas, i.e. the effect of trauma on Marmas. The anatomical correlation with modern science was also presented.

The present article, which is part- 3 of this study, deals with the foundational elements of the Science of Marma with regards to its use in Yoga and other ancient Indian traditions. The correlation between the Marma Science and Yogic Science, including the different limbs of Ashtanga Yoga, has been explored. Its use in various ancient Indian traditions, both as a martial art for self defense and inflicting injury on the opponents, and as a therapeutic technique for healing purposes, has also been expolored.

\section{Marma in Some Ancient Indian Traditions}

Marma Science is known in different ways in different parts, traditions and languages of the country. In Kerala it is used in Kalaripayattu, in Tamil Nadu it is used in Varma-kalai, in Malayalam it is called Marma kala, in Sinhala it is called Maru kala, and in Telugu it is called Marma vidyaka [14]. Siddha system of medicine calls Marma as 'Varma' [14,20]. When used for healing applications, for the treatment of various diseases, it is called 'Vaidiyamurai' in Siddha system of medicine [14,20,45]. It is called 'Varma adi' or 'Marma adi', when it is used for combat purposes; this term means striking at the vital spots, either by hand or by a blunt weapon, wherein the nerves, veins, tendons, bone joints are the primary targets of the strikes [14]. Several ancient Indian martial art traditions including Kalari martial art of Kerala, Dhanurveda (Vedic archery), Malla Purana (wrestling) and Vajra Mushthi (boxing) used energy points (Marmas), both for causing injury to the opponents, as well as in the form of a therapeutic procedure [12].

Further details about the use of Marma Science in some ancient Indian traditions, for which detailed description is readily available, is as follows.

\subsection{Marma and Kalaripayat}

In Kerala, Kalaripayat is practiced, which is one of the most ancient Martial Art tradition of India. In Malayalam, "Kalari" literally means - 'practice-ground', and "Payattu" means - 'exercise' [20]. The knowledge of Marman (vulnerable pressure points of the body) is employed by the practitioners of Kalaripayat as a health promoting technique [16,20]. When the knowledge of Kalaripayat went abroad, the concept of marman points was carried along with it as an essential component of martial arts [16].

With regards to its use as a healing technique, some practitioners are known to use thin 
bamboo sticks, which are applied and held in place on specific body points, in order to heal the patients; this ancient technique is known as 'Shalaka Shastra', and it may be considered as the origin of the modern acupuncture [16]. The practitioners found these specific vulnerable points after deep and careful examination of their own body; they experimented on their own bodies by giving themselves violent blows to identify these points, as well as analyze their sensitivity [16].

Kalaripayattu masters refer to three texts regarding the vital spots [46], which are -

1. Marmmanidanam (Diagnosis of vital spots)

2. Granthavarimarmma chikitsa (gives the method of identification and therapeutic procedures that are to be followed in healing vital spot injuries)

3. Marmmayogam (this is the handbook of Kalaripayattu practitioner that contains emptyhand practical fighting applications, as well as the method of emergency revivals for sixty four most vital spots - Kulabhyasamarmmam). The empty-hand techniques would have been useful in cases where either the weapon of the practitioner was lost or broken during the combat, or if the practitioner was unarmed during attack [46].

The texts Marmmanidanam and Marmmarahasyangal identify a total of 107 vital spots (just like Sushruta Samhita) by using forty three names [46].

The text Granthavarimarmma chikitsa or Marmmani Chikitsa lists the medicinal preparations and therapeutic procedures for the treatment of penetrating injuries to the 107 vital spots (as identified by Acharya Sushruta) [46].

\subsection{Siddha system perspective}

Marma Science is an integral part of the Siddha system of medicine, which is mainly practiced in South India; Marma or vital spot is called 'Varmam' in Siddha medicine, which means a protective covering or shield (kavacha or body armor) [14,20,45]. 'Varma-kalai' is the common name for this science [14,20]. The literal meaning of 'Varmam' is - the 'Science of life force' [45]. Varmam has been traditionally practiced in the South Indian state of Tamil Nadu, both as a martial art for self defense, as well as as a therapeutic technique for healing purposes [20,45]; from generation to generation, its knowledge has been transferred orally from the masters to the disciples.

As per ancient belief, Lord Shiva (supposed to be the First Siddha) taught Varma-kalai to his wife Parvathi, who in turn taught it to her son Murugan. Later on Murugan taught this skill to sage Agasthiyar and Boghar, from whom it was transferred to their students [45].

Varma-kalai includes 108 Varmam points (vital spots), which are supposed to be the source for healthy long life, as well as diseases and death [45]. The Varmam points are classified into two groups as per their effect on the body [45] -

(a) Paduvarmam

(b) Thoduvarmam

-12 points

The Paduvarmam points are core Varmam points of Varma-kalai; these points are associated with the pathway of the Saram, that runs alongside the dasanadi (ten types of pulse) and dasavayu (ten types of air) [45]. As a result, if a Paduvarmam point is injured, it will not just affect the site of trauma, but the equilibrium of many other locations associated with its path will be disturbed [45].

Each Paduvarmam point is connected to eight Thoduvarmam points, that are affected by the stimulation of the specific Paduvarmam point [45]. All the Thoduvarmam points are not fatal; only a few of these points may lead to disability or death [45].

Varmam points are also categorized according to the Tri-Doshas of an individual, as follows [45] -

$\begin{array}{ll}\text { Vata Varmam } & -64 \text { points } \\ \text { Pitta Varmam } & -26 \text { points } \\ \text { Kapha Varmam } & -06 \text { points } \\ \text { Vata thotha Varmam } & -04 \text { points } \\ \text { Pitta thotha Varmam } & -05 \text { points } \\ \text { Kapha thotha Varmam } & -03 \text { points }\end{array}$


Varmam points are also classified according to the Panchamahabhootas (five elements), as follows [45] -

$\begin{array}{ll}\text { Earth } & -36 \text { points } \\ \text { Water } & -15 \text { points } \\ \text { Fire } & -32 \text { points } \\ \text { Air } & -13 \text { points } \\ \text { Sky } & -12 \text { points }\end{array}$
[45] -

With regards to the distribution in the body, the Varmam points can be classified as follows

$\begin{array}{ll}\text { Supra-clavicular region } & -25 \text { points } \\ \text { Neck to navel } & -45 \text { points } \\ \text { Navel to anus } & -09 \text { points } \\ \text { Hands } & -14 \text { points } \\ \text { Legs } & -15 \text { points }\end{array}$

The concept of the occurrence of a disease and its treatment in Varma-kalai, and the Siddha system of medicine, is very similar to that in Marma Science. In Varma-kalai, the vital life force is supposed to flow like a stream from one Varmam point to another, and a disease occurs at a location if there is an obstruction in this flow, leading to the stagnation of the energy at the nearby adangal (reservoir of life energy) [45]. In Siddha system of medicine, 'Piraanam' (vital life force or 'Prana') is supposed to circulate through a network of Naati (Nadis) channels [20]. Varmam points lie on the Naati channels and are the sites where the Piraanam resides [20]. An imbalance in the flow of Piraanam causes disease, and the Varmam points are stimulated to treat the disease by regaining the balance in the flow of Piraanam [20]. In Siddha system of medicine, the use of Varmam points for healing purposes is called 'Vaidiyamurai', their use for combat purposes is called 'Adimurai'; Adimurai means striking these points, where the primary targets are veins, nerves, tendons, organs and bone joints [45].

Thus, there is a striking similarity between the above mentioned ancient Indian traditional techniques and the Marma Science; all these techniques deal with the stimulation of the vital spots to rectify the flow of Prana in the body, leading to the corresponding healing effect.

\section{Marma and Yoga}

According to the scriptures, there is a prominent correlation between the Marma Science and the Yoga. In Patanjal Yoga Sutra, Maharshi Patanjali has described the eight limbs of Yoga as 'Ashtanga Yoga' (Patanjal Yoga Sutra, Samadhi Pada 29) [47]. In the present section, the correlation between different limbs of Ashtanga Yoga and Marma Science is being presented.

The ancient sages (Rishis) gave a prominent place to the Yogasanas (Yogic postures) in Yoga Sadhana because, besides being extremely useful for the protection of health, they sustain the activity of the 'Havya Vaha' and 'Kavya Vaha' Tadit Shakti (bio-electric power), that reside in the Marma locations [48]. The positive electricity named 'Havya Vaha' resides in the Marmas of the head and the torso, while the negative electricity named 'Kavya Vaha' resides in the Marmas of the hands and legs [48]. Vayu Purana [49] and Koorma Purana [50] state that the Havya Vahini and Kavya Vahini powers are related to Agni (fire). The fire (Agni) of Devatas (deities) is in the form of Havyavahan, and the fire (Agni) of Pitars (ancestors) is in the form of Kavyavahan [49]. Thus, the Marmas can be regarded as a part of the subtle physiology of the body, which is based on subtle power points and energy currents; a knowledge of this subtle physiology can help us attune ourselves to the subtle energy currents prevailing in the cosmos [11].

The ancient sages (Rishis) observed that even after maintaining a healthy diet and routine, proper arrangement of rest and exercise, many a times due to unknown subtle causes, the Marma points are distorted / damaged, which leads to the imbalance of the Havya Vaha and Kavya Vaha Tadit Shakti (bio-electric power) residing in the Marma points, resulting in the occurrence of disease and 
weakness [48]. In order to provide relief from this suffering by regaining this balance, the ancient sages invented Yogasanas (Yogic postures) through long term research and experience [48].

Marma points are not stimulated through common day to day hard work and exercise [48]. Yogasanas have a direct influence on the Marma points, and play an important role in their refinement, stability and nourishment [48]. Yogasanas cause the periodic contraction and expansion of the physical and subtle body parts like veins, muscles, vertebrae, etc., resulting in the removal of the toxins stored there; then through regular cleaning action, new toxins are not allowed to get stored there, and a disease-free healthy state is obtained [48].

Yogasanas and Pranayama affect the body and the mind by stimulating the Marma points $[8,11]$. The Marmas are stimulated through the stretching, vibration, rhythmic movement and pressure caused by these practices; subsequently, the functioning of the respective organs with which the specific Marmas are associated, also gets affected [7]. The Marmas of the chest, abdomen and back are affected by the forward and backward bending Yogasanas [7].

The practice of Yogasanas ensures proper flow of Prana through different Marma locations [11]. Marmas serve as primary energy centers for Yogasanas and Dhyana (meditation) [11]. The energy of the limbs, joints and spine is affected by Yogasanas; these locations are sites of important Marma points [11]. Marmas are connected to the Nadis (subtle nervous system) and Chakras (subtle energy centers) of the subtle body; thus, the stimulation of Marmas affects both the physical and the subtle bodies (feelings, emotions and subtle energy currents), as well as ensures the proper exchange of energy between them, which results in better health and enhanced vitality [11].

As Marmas are the seats of Prana, the vital life force that governs the physical and subtle processes of the body, the stimulation of Marmas can alter the state of Prana at these locations, causing a corresponding effect on the physical and subtle processes, and the flow of energy [11]. Therefore, by the proper stimulation of Marmas, the Prana can be modulated in such a way that it can be used to remove blockages, and decrease or enhance the physical and subtle energy currents within the body, resulting in the corresponding healing effect [11].

\subsection{Marma and Shatkarma}

Shatkarmas are the six cleansing techniques, as devised by Hatha yoga (Hatha Pradipika 2/22) [51]. It is supposed that when Shatkarma purifies the different body systems then the energy (prana) can flow freely through the body [51].

Table 1 lists the effect of Yogic Shatkarma practices on Marma points, and the corresponding therapeutic benefits. The affected Marmas were selected based on the physical region of the body being affected by the activity associated with the specific Shatkarma practices, as well as the therapeutic benefits caused by the same. 
Table 1: Effect of Yogic Shatkarma practices on Marma points, and the corresponding therapeutic benefits [Hatha Pradipika - H.P.] [51,52].

\begin{tabular}{|l|l|l|l|l|}
\hline S.N. & Shatkarma & \multicolumn{1}{|c|}{ Affected Marmas } & \multicolumn{1}{|c|}{ Benefits } & Reference \\
\hline 1. & Dhauti & $\begin{array}{l}\text { Nabhi, Vasti, } \\
\text { Kanthagata and } \\
\text { Urogata Marmas }\end{array}$ & $\begin{array}{l}\text { Cough, Asthama, Spleen disorders, Skin } \\
\text { disorders, all 20 types of Kapha disorders }\end{array}$ & H.P. 2/ 25 \\
\hline 2. & Basti & Guda, Vasti, Nabhi & $\begin{array}{l}\text { Gulma (gas pocket in the abdomen), Spleen } \\
\text { disorders, Abdominal disorders, Ascites, } \\
\text { Disorders of Vata-Pitta-Kapha }\end{array}$ & H.P. 2/28 \\
\hline 3. & Neti & $\begin{array}{l}\text { Shringataka, Phana, } \\
\text { Sthapni }\end{array}$ & $\begin{array}{l}\text { Disorders of Supraclavicular region, purify } \\
\text { Kapal region (brain), clear vision }\end{array}$ & H.P. $2 / 31$ \\
\hline 4. & Trataka & $\begin{array}{l}\text { Apanga, Avarta, } \\
\text { Shringataka, Sthapni }\end{array}$ & Eye disorders, Drowziness & H.P. $2 / 33$ \\
\hline 5. & Nauli & Nabhi, Vasti & $\begin{array}{l}\text { Digestive disorders and useful for several } \\
\text { diseases }\end{array}$ & H.P. $2 / 35$ \\
\hline 6. & Kapalbhati & Shringataka, Sthapni & Kapha disorders, Obesity & H.P. 2/36 \\
\hline
\end{tabular}

\subsection{Marma and Yogasanas}

Table 2 lists the Marma points stimulated by different Yogasanas (Yogic postures), and the corresponding therapeutic benefits.

Table 2: Marma points stimulated by different Yogasanas (Yogic postures), and the corresponding therapeutic benefits [Gherand Samhita - Gh.S.] [53].

\begin{tabular}{|c|c|c|c|c|}
\hline Asana & $\begin{array}{l}\text { Affected body } \\
\text { part/ organ }\end{array}$ & $\begin{array}{l}\text { Stimulated } \\
\text { Marma }\end{array}$ & Benefits & $\begin{array}{c}\text { Ref. } \\
\text { (Pg.No.) }\end{array}$ \\
\hline Siddhasana & $\begin{array}{l}\text { Excretory/ } \\
\text { Reproductive } \\
\text { organs }\end{array}$ & Guda, Vasti & $\begin{array}{l}\text { Nightfall, Leucorrhoea, control over } \\
\text { mind, may achieve thoughtless stage of } \\
\text { mind }\end{array}$ & Gh.S. 128 \\
\hline Padmasana & Base of the spine & Vitapa & $\begin{array}{l}\text { Physical and mental stability and peace, } \\
\text { reduction in internal anxiety }\end{array}$ & $\begin{array}{l}\text { Gh.S. } \\
131,132\end{array}$ \\
\hline Vajrasana & $\begin{array}{l}\text { Digestive, } \\
\text { Excretory, } \\
\text { Reproductive } \\
\text { system }\end{array}$ & $\begin{array}{l}\text { Katikataruna, } \\
\text { Vitapa }\end{array}$ & $\begin{array}{l}\text { Constipation, hyperacidity, indigestion, } \\
\text { peptic ulcer, problems related to } \\
\text { reproductive and excretory system - } \\
\text { irregular menses, hydrocele, hernia }\end{array}$ & $\begin{array}{l}\text { Gh.S. } \\
140,141\end{array}$ \\
\hline Matsyendrasana & $\begin{array}{l}\text { Abdomen region - } \\
\text { liver, spleen, } \\
\text { pancreas, } \\
\text { intestine, urinary } \\
\text { bladder, kideny }\end{array}$ & $\begin{array}{l}\text { Nabhi, Vasti, } \\
\text { Parshvasandhi }\end{array}$ & $\begin{array}{l}\text { digestive disorders, diabetes, for the } \\
\text { flexibility of back and spinal cord, } \\
\text { backache, stiffness, osteophytes, urinary } \\
\text { disorders, constipation, colitis, irregular } \\
\text { menses }\end{array}$ & $\begin{array}{l}\text { Gh.S. } \\
162,163\end{array}$ \\
\hline Simhasana & $\begin{array}{l}\text { Neck, throat, } \\
\text { brain, spinal cord }\end{array}$ & $\begin{array}{l}\text { Nila, Manya, } \\
\text { Matruka, } \\
\text { Krukatika }\end{array}$ & $\begin{array}{l}\text { Balance hypothalamic - limbic system, } \\
\text { speech related problems - stammering, } \\
\text { hoarseness of voice, etc., tonsillitis, } \\
\text { mouth ulcer, depressive and introvert } \\
\text { person }\end{array}$ & $\begin{array}{l}\text { Gh.S. } \\
145,146\end{array}$ \\
\hline Gomukhasana & $\begin{array}{l}\text { Reproductive } \\
\text { organs, lungs and } \\
\text { other respiratory } \\
\text { organs, upper part } \\
\text { of back, shoulder }\end{array}$ & $\begin{array}{l}\text { Vitapa, } \\
\text { Ansaphalaka, } \\
\text { Vruhati, } \\
\text { Stanamoola, } \\
\text { Stanarohita }\end{array}$ & $\begin{array}{l}\text { Hydrocele, prolapse of uterus, Asthma, } \\
\text { Bronchitis, Cervical spondylosis, Frozen } \\
\text { shoulder, Writer's cramp }\end{array}$ & $\begin{array}{l}\text { Gh.S. } \\
147,148\end{array}$ \\
\hline
\end{tabular}




\begin{tabular}{|c|c|c|c|c|}
\hline Dhanurasana & $\begin{array}{l}\text { Whole spinal } \\
\text { cord, liver, } \\
\text { stomach, lungs, } \\
\text { heart, kidney, } \\
\text { pancreas, adrenal } \\
\text { gland, intestine, } \\
\text { upper-extremity, } \\
\text { lower-extremity, } \\
\text { head }\end{array}$ & $\begin{array}{l}\text { All marmas of } \\
\text { abdomen, } \\
\text { chest and } \\
\text { back }\end{array}$ & $\begin{array}{l}\text { Stiffness of vertebral column, slip disc, } \\
\text { sciatica, spondylitis, improve digestion, } \\
\text { worms, flatulence, obesity, liver } \\
\text { insufficiency, constipation, diabetes, } \\
\text { colitis, menstrual disorders, respiratory } \\
\text { problems, hormonal disbalance }\end{array}$ & $\begin{array}{l}\text { Gh.S. } \\
152,153\end{array}$ \\
\hline $\begin{array}{l}\text { Pashchimottanas } \\
\text { ana }\end{array}$ & $\begin{array}{l}\text { Abdomen, } \\
\text { excretory and } \\
\text { reproductive } \\
\text { system, kidney, } \\
\text { hip region, lower- } \\
\text { extremity }\end{array}$ & $\begin{array}{l}\text { All marmas of } \\
\text { abdomen, } \\
\text { chest and } \\
\text { back }\end{array}$ & $\begin{array}{l}\text { Liver insufficiency, diabetes, menstrual } \\
\text { disorders, colitis, bronchitis, } \\
\text { eosinophilia, scoliosis, obesity, renal } \\
\text { disorders, respiratory problems }\end{array}$ & $\begin{array}{l}\text { Gh.S. } \\
168,169\end{array}$ \\
\hline Bhujangasana & $\begin{array}{l}\text { Spinal cord, } \\
\text { Abdomen, } \\
\text { Kideny, Liver, } \\
\text { Adrenal gland, } \\
\text { Thyroid gland, } \\
\text { Reproductive } \\
\text { organs, neck }\end{array}$ & $\begin{array}{l}\text { All marmas of } \\
\text { abdomen, } \\
\text { chest, back } \\
\text { and neck }\end{array}$ & $\begin{array}{l}\text { Increase flexibility of spinal cord, slip } \\
\text { disc, lumbago, menstrual disorders, } \\
\text { constipation, hypothyroidism, Renal } \\
\text { disorders, increase appetite }\end{array}$ & $\begin{array}{l}\text { Gh.S. } \\
198,199\end{array}$ \\
\hline Mayurasana & $\begin{array}{l}\text { Navel region, } \\
\text { stomach, liver, } \\
\text { intestine, urinary } \\
\text { bladder }\end{array}$ & $\begin{array}{l}\text { Nabhi, Vasti, } \\
\text { Manibandha, } \\
\text { Kurpara }\end{array}$ & $\begin{array}{l}\text { Constipation, diabetes, liver and renal } \\
\text { insufficiency, skin disorders, hormonal } \\
\text { disbalance, to balance Tridoshas (Vata, } \\
\text { Pitta, Kapha) }\end{array}$ & $\begin{array}{l}\text { Gh.S. } \\
174,175\end{array}$ \\
\hline
\end{tabular}

\subsection{Marma and Pranayama}

चले वाते चले चित्तं निश्चले निश्चलं भवेत् ।
योगी स्थाणुत्वमाप्नोति ततो वायुं निरोधयेत् ।।

(Hatha Pradipika 2/2) [51,52]

Hindi Commentary: वायु के चलायमान होने पर चित्त भी चंचल होता है और वायु के निश्चल हो जाने पर चित्त भी स्थिर हो जाता है, और तब योगी स्थिरता को प्राप्त करता है। अत: प्राणायाम का अभ्यास करना चाहिए। (Hatha Pradipika 2/2) [51,52]

English Translation: When Vayu (air) freely flows around, then the Chitta (subtle mind) is also unsteady; and when the Vayu halts, Chitta also becomes steady, and then a Yogi (practitioner of Yoga) attains complete steadiness. Therefore, Pranayama must be practiced.

Hatha Pradipika - 2/5 [51,52] states that when all the dirty Nadis (subtle veins and nerves) are purified, then only a Sadhak (practitioner of spirituality) becomes capable of properly controlling the Prana (Vayu).

Table 3 lists the affect of Pranayama on Marma points, and the corresponding therapeutic benefits. 
Table 3: Effect of Pranayama on Marma points, and the corresponding therapeutic benefits (Hatha Pradipika - H.P.) [51,52].

\begin{tabular}{|l|l|l|l|l|}
\hline S.N. & Pranayama & \multicolumn{1}{|c|}{ Affected Marmas } & \multicolumn{1}{|c|}{ Benefits } & Reference \\
\hline 1. & Suryabhedan & $\begin{array}{l}\text { Marmas of Supraclavicular } \\
\text { region (Heating effect) }\end{array}$ & $\begin{array}{l}\text { Cleanses the head region, provides } \\
\text { relief in Vata disorders, worm } \\
\text { infestations }\end{array}$ & H.P. 2/50 \\
\hline 2. & Ujjai & $\begin{array}{l}\text { Kanthagata marmas (Nila, } \\
\text { Manya, Matrika) }\end{array}$ & $\begin{array}{l}\text { Provides relief in Kapha disorders, } \\
\text { throat disorders, nervine disorders, } \\
\text { ascites, genital disorders }\end{array}$ & H.P. 2/52,53 \\
\hline 3. & Seetkari & $\begin{array}{l}\text { Marmas of Supraclavicular } \\
\text { region (Cooling effect) }\end{array}$ & $\begin{array}{l}\text { Able to conquer hunger, thirst, sleep, } \\
\text { fatigue }\end{array}$ & H.P. 2/55 \\
\hline 4. & Sheetali & $\begin{array}{l}\text { Marmas of Supraclavicular } \\
\text { region (Cooling effect) }\end{array}$ & $\begin{array}{l}\text { Provides relief in gulma, spleen } \\
\text { disorders, fever, Pitta disorders; able to } \\
\text { conquer hunger, thirst; destroys the } \\
\text { effect of poison }\end{array}$ & H.P. 2/58 \\
\hline 5. & Bhastrika & $\begin{array}{l}\text { Marmas of Chest, Abdomen } \\
\text { and Supraclavicular region }\end{array}$ & $\begin{array}{l}\text { Provides relief in Vata, Pitta, Kapha } \\
\text { related disorders; enhances the } \\
\text { digestive fire }\end{array}$ & H.P. 2/65 \\
\hline 6. & Bhramari & Shiromarma (Head Marmas) & $\begin{array}{l}\text { Arousal of immense peace and } \\
\text { happiness in the Chitta (inner } \\
\text { conscience) }\end{array}$ & H.P. 2/68 \\
\hline
\end{tabular}

\subsection{Marma and Bandhas}

Table 4 lists the Marma points stimulated by different Yogic Bandhas and the affected dosha.

Table 4: Marma points stimulated by different Yogic Bandhas and the affected dosha [11].

\begin{tabular}{|l|l|l|l|}
\hline \multicolumn{1}{|c|}{ Bandha } & Affected body part/ organ & Stimulated Marma & \multicolumn{1}{c|}{ Affected Dosha } \\
\hline Moola & Base of the spine & Guda, Vasti & Vata \\
\hline Uddiyana & Stomach region & Nabhi & Pitta \\
\hline Jalandhara & Throat region & Nila, Manya & Kapha \\
\hline
\end{tabular}

\subsection{Marma and Pratyahara \& Dharana (Concentration)}

Out of the eight limbs of Yoga, Pratyahara is the fifth limb, which deals with the withdrawal of the sensory perceptions from external pursuits, and making the mind introvert to see within and internalize all forms of energies (Patanjal Yoga Sutra, Sadhana Pad, 54) [47]. It helps in internalizing the consciousness and Prana, which in turn can contribute to spiritual upliftment and healing [11]; probably, this is the reason why the ancient sages greatly appreciated the practice of Pratyahara on Marma sites, as described below.

As Marmas are the seats of Prana, they can play a vital role in the practice of Pratyahara, as has been described in Shandilyopanishada [54] and Vashishtha Samhita [55].

Shandilyopanishada discusses the performance of Pratyahara on 18 Marma locations as follows [54].

अष्टादशसु मर्मस्थानेषु क्रमाद्धारणं प्रत्याहार:। $\quad$ (Shandilyopanishada 8/1) [54]

Hindi Translation - अट्ठारह मर्म स्थलों में क्रमश: धारणा करना (उन स्थानों पर स्थित चेतन दिव्य प्रवाहों के साथ चित्त का तादात्म्य स्थापित करके दिव्यानुभूति प्राप्त करना) ही प्रत्याहार है। [54]

English Translation - Pratyahara is the process of doing Dharana (attaining divine experience by establishing the linkage of the Chitta, inner conscience, with the lively divine currents present at those locations) successively on the eighteen Marma locations. 
पादाझुुष्णुल्फजड्धाजानूरुपायुमेढ्रनाभिहृदयकणठकूपतालुनासाक्षिभूमधध्यललाटमूर्ध्नि स्थानानि ।

तेषुक्रमादारोहावरोहक्रमेण प्रत्याहरेत् ॥ (Shandilyopanishada 8/2) [54]

Hindi Translation - पैर का अँगूठा, गुल्फ़, जंघा, जानु, उरु, गुदा, लिंग, नाभि, हृदय, कण्ठकूप, तालु, नासिका, आँख, भ्रूमध्य, ललाट एवं सिर - इन सभी स्थलों पर उतार चढ़ाव के क्रम से प्रत्याहार करना चाहिए। [54]

English Translation - Toe of the foot, Gulpha (ankle), Jangha (lower leg), Janu (knee), Uru, Guda (anus), Linga (genital), Nabhi (navel), Hridaya (heart), Kanthakoopa (root of neck), Talu (palate), Nasika (nose), Ankha (eye), Bhroomadhya (area in between the eyebrows), Lalata (forehead) and Sira (head) - on all these locations Pratyahara should be done in the order of going up and down.

Vashishtha Samhita (3/61 to 3/64) [55] also describes the practice of Pratyahara on 18 specific Marma locations, as follows.

प्रत्याहारं प्रशंसन्ति संयुता योगिन: सदा । अष्टादशसु यद्वायोर्मर्मस्थानेषु धारणम् ।

स्थानात् स्थानात् समाकृष्य प्रत्याहार: स चोत्तम: ।।

(Vashishtha Samhita 3/61) [55]

Hindi Translation - अभ्यास में लगे हुए योगी सदा उस प्रत्याहार की प्रशंसा किया करते हैं, जिसमें अट्ठारहों मर्म स्थानों में वायु को स्थिर करना, फिर एक एक स्थान से उचित रीति से वायु को खींचना होता है, वही उत्तम प्रत्याहार है। [55]

English Translation - The dedicated Yogis (practitioners of Yoga) always praise that Pratyahara, which involves (concentration (Dharana) of / the feeling of) stabilizing the Vayu (Prana - vital life force) in all the eighteen Marma locations, and then pulling / drawing the Vayu (Prana) in proper manner from each of these locations - this is the best form of Pratyahara [11].

पादाड़ु.्ठऔ च गुल्फ़ौ च जड्धन्धम्यौ तथैव च । चित्योर्मूले च जानू च मध्ये चोरुद्वयस्य च ।।

(Vashishtha Samhita 3/62) [55]

पायुमूलं तत: पश्चान्मध्यदेहं च मेढ्रकम् । नाभिं च हृदयं वत्स कण्ठकूपस्तथैव च ।।

(Vashishtha Samhita 3/63) [55]

तालुमूलं च नासाया: मूलं चाक्ष्णोश्च मध्यमम् । भ्रुवोर्मध्ये ललाटं च मूर्धा च मुनिसत्तम ।

मर्मस्थानानि चैतानि मानं तेषां पृथक् श्रृणु ।। (Vashishtha Samhita 3/64) [55]

Hindi Translation - पाँव के अंगूठे, दोनों टखने, जंघाओं के मध्य, दोनों चिति (घुटने के नीचे का भाग) के मूल, दोनों घुटने, उरुओं के मध्य, गुदा का मूल, देह मध्य, लिंग, नाभि, हृदय, कण्ठ कूप, तालुमूल, नासामूल, दोनों आँखों के मध्य बिन्दु, दोनों भौहों के मध्य, मस्तक तथा मूर्धा - ये 18 मर्म स्थान कहलाते हैं। [55]

English Translation - Toes of the foot, both the ankles, middle of the Jangha (lower leg), the root of both the Chiti (the part below the knee), both the knees, middle of the Uru (thigh), root of anus, middle of torso, male genital, navel, heart, root of neck, top of palate, root of nose, area between both the eyes, area between both the eyebrows, forehead and Murdha (back of palate) - these are called the 18 Marma locations.

The physical distance between these 18 Marma locations has been described in Vashishtha Samhita, as given in Table 5 (Vashishtha Samhita 3/65 to 3/73) [55]; the names of the Marma points corresponding to these locations are also given in Table 5 [14]. 
Table 5: The physical distance between the 18 Marma locations described in Vashishtha Samhita [V.S.] [55], and the names of the corresponding Marma points [14].

\begin{tabular}{|l|l|l|l|l|}
\hline $\begin{array}{c}\text { S. } \\
\text { N. }\end{array}$ & $\begin{array}{c}\text { Marma sthana } \\
\text { (Marma region) }\end{array}$ & $\begin{array}{c}\text { Corresponding } \\
\text { Marma point [14] }\end{array}$ & $\begin{array}{c}\text { Distance between subsequent Marma } \\
\text { sthanas (in Angula, i.e. number of } \\
\text { finger width) }\end{array}$ & $\begin{array}{l}\text { Reference } \\
\text { [V.S.] [55] }\end{array}$ \\
\hline 1. & Padangushtha & Kshipra & 0 & $3 / 65$ \\
\hline 2. & Gulpha & Gulpha & 4.5 fingers above from Padangushtha & $3 / 65$ \\
\hline 3. & Pindikamadhya & Indravasti & 10 fingers above from Gulpha & $3 / 66$ \\
\hline 4. & Janumoola & --- & 11 fingers above from Pindikamadhya & $3 / 66$ \\
\hline 5. & Janu & Janu & 2.5 fingers above from Janumoola & $3 / 67$ \\
\hline 6. & Urumadhya & Urvi & 9 fingers above from Janu & $3 / 67$ \\
\hline 7. & Payumoola & Guda & 9 fingers above from Urumadhya & $3 / 68$ \\
\hline 8. & Dehamadhya & & 2.5 fingers above from Payumoola & $3 / 68$ \\
\hline 9. & Linga & Vitapa & 2.5 fingers above from Dehamadhya & $3 / 69$ \\
\hline 10. & Nabhi & Nabhi & 10.5 fingers above from Linga & $3 / 69$ \\
\hline 11. & Hridayamadhya & Hridaya & 14 fingers above from Nabhi & $3 / 70$ \\
\hline 12. & Kanthakoopa & Nila, Manya & 6 fingers above from Hridayamadhya & $3 / 70$ \\
\hline 13. & Jihvamoola & Shringataka & 4 fingers above from Kanthakoopa & $3 / 71$ \\
\hline 14. & Nasamoola & Shringataka & 4 fingers above from Jihvamoola & $3 / 71$ \\
\hline 15. & Netrapradesha & Apanga & $1 / 2$ finger above from Nasamoola & $3 / 72$ \\
\hline 16. & Bhroomadhya & Sthapni & $1 / 2$ finger above from Netrapradesha & $3 / 72$ \\
\hline 17. & Lalaata & & 3 fingers above from Bhroomadhya & $3 / 73$ \\
\hline 18. & Brahmarandhra & Adhipati & 3 fingers above from Lalaata & $3 / 73$ \\
\hline & & & \\
\hline
\end{tabular}

Vashishtha Samhita (3/74) [55] states that the process of taking the Vayu (Prana) from the mind to these locations, drawing the Vayu through these locations one by one, and stabilizing it there, is considered very good form of Pratyahara. (Hindi Translation - इन स्थानों में मन से वायु को उठाकर, एक एक स्थान से क्रमश: दूसरे स्थान में खींचकर स्थिर करते जाना उत्तम प्रत्याहार माना गया है। (Vashishtha Samhita 3/74) [55])

\subsection{Marma and Dhyana (Meditation)}

If Dhyana (meditation) is practiced on the Marma points, on which the practice of Pratyahara has been suggested by the ancient sages / Rishis, then it can lead to the balancing of the Pranic flow in the body and mind, and thus provide relief in all types of diseases and sufferings [11]. With regards to the methodology of this Dhyana, Frawley et al. (2015) [11] state that by using inhalation and exhalation, muscle flexion and relaxation, and the power of attention, the Prana should be drawn to each of these Marma points. The attention may be focused on a specific Marma site as well, in order to heal that specific area [11].

\subsection{Marma and Chakras}

The literal meaning of word 'Chakra' is 'wheel' or 'circle', but in the yogic contex it means 'vortex' or 'whirlpool'. The chakras are vortices of pranic energy at specific areas in the body which controls the circulation of Prana permeating the entire human structure. In this regard the chakras may 
be correlated with the Pranayatana (seats of Prana). Acharya Charaka and Acharya Vagbhatta have mentioned ten Pranayatana in the body (Charaka Sharira 7/9 [42], Ashtanga Sangraha Sharira 5/59 [40,41]). Out of these ten Pranayatana, six given by Acharya Charaka (Charaka Sharira 7/9) [42] and seven by Acharya Vagbhatta (Ashtanga Sangraha Sharira 5/60) [40,41] are called as 'Mahamarmas' (very important marmas), that correspond almost identically with the location of seven chakras, as mentioned in Table 6. The corresponding verses of Ashtanga Sangraha Sharira 5/59,60 [40,41] are as follows:

$$
\begin{aligned}
& \text { दश प्राणायतनानि मूर्धा जिह्वाबन्धनं कण्ठो हृदयं नाभिर्बस्तिगुद: शुक्रमोजो रक्तम् । } \\
& \text { एषामाद्यानि सप्त पुनर्महामर्मसंज्ञानि ।। } \\
& \text { (Ashtanga Sangraha, Sharira Sthana 5/59,60) [40,41] }
\end{aligned}
$$

On a physical level, chakras are associated with the major nerve plexus and endocrine glands in the body [56].

Each chakra is a switch which turns on or opens up specific areas of the brain. In most people these psychic centers lie dormant and inactive [56]. Marma point stimulation by concentration on the chakras can modulate the flow of energy (prana) through these chakras and helps to activate them. This in turn awakens the dormant areas in the brain, and the corresponding faculties in the psychic and mental bodies, allowing one to experience higher planes of consciousness, which are normally inaccessible [56].

The major chakras are seven in number, and are located along the pathway of Sushumna, which flows through the center of the spinal cord [56]. The seven major chakras have the role of absorbing energy and channelizing it to body's nerve centers [14].

The role of chakras is very important in Marma Science. Each of the seven major chakras, and their corresponding region of the back is a kind of Marma, and these Marmas or Pranic centers of the subtle body energize all the other Marmas or Pranic centers of the physical body $[11,14]$.

The location of chakras, their anatomical correlation and their corresponding Marma points are described in Table 6.

Table 6: Location, anatomical correlation, and the corresponding Marma points and

\begin{tabular}{|c|c|c|c|c|c|}
\hline $\begin{array}{l}\text { S. } \\
\text { N. }\end{array}$ & Chakra & $\begin{array}{c}\text { Related } \\
\text { Pranayatana* }\end{array}$ & $\begin{array}{l}\text { Related } \\
\text { Marma }\end{array}$ & Location & $\begin{array}{l}\text { Anatomical } \\
\text { correlation }\end{array}$ \\
\hline 1. & Muladhara & Guda & Guda & $\begin{array}{l}\text { At the Perineum (in males) } \\
\text { At the Cervix (in females) }\end{array}$ & Pelvic plexus \\
\hline 2. & Swadhisthana & Vasti & Vasti & $\begin{array}{l}\text { Behind the Genital organs, } \\
\text { approximately two fingers } \\
\text { above Muladhara Chakra }\end{array}$ & Hypogastric plexus \\
\hline 3. & Manipura & Nabhi & Nabhi & Behind the Navel & $\begin{array}{l}\text { Solar or Epigastric } \\
\text { plexus }\end{array}$ \\
\hline 4. & Anahata & Hridaya & Hridaya & $\begin{array}{l}\text { Behind the Sternum, at the } \\
\text { level of Heart }\end{array}$ & Cardiac plexus \\
\hline 5. & Vishuddhi & Kantha & Matrika & $\begin{array}{l}\text { Behind the Throat pit (at the } \\
\text { back of neck) }\end{array}$ & Carotid plexus \\
\hline 6. & Agya & Jihvabandhana & Sthapni & $\begin{array}{l}\text { Behind the Eyebrow center } \\
\text { (in the mid brain) }\end{array}$ & Medulla plexus \\
\hline 7. & Sahasrara & Murdha & Adhipati & At the Crown of the head & Cerebral gland \\
\hline
\end{tabular}
Pranayatana for the seven Chakras $[11,14,56]$.

*Ashtanga Sangraha Sharira Sthana 5/59,60 [40,41]

Thus, it may be understood that by working on marma points, the Prana may be controlled [11]. The control over the Prana can in turn lead to control over the autonomic nervous system, sensory and motor organs, as well as the entire mind-body system, which opens the doors for the 
access of the higher realms of consciousness $[3,11]$.

\section{Conclusion}

The present article explored the foundational elements of the Science of Marma with regards to its use in Yoga and other ancient Indian traditions.

It is observed that the science of vital spots (Marmas) is an integral part of several ancient Indian traditions including the Kalari martial art tradition of Kerala, and the Varma-kalai of Tamil Nadu. This science has been used both as a martial art for self defense and inflicting injury on the opponents, and as a therapeutic technique for healing purposes. Siddha system of medicine calls Marma as 'Varma', and regularly employs the practice of stimulation of these vital spots for the treatment of various ailments. With regards to the conceptual foundation of their healing application in these traditions, the stimulation of the vital spots is supposed to rectify the flow of Prana in the body, leading to the corresponding healing effect.

According to the ancient scriptures, there is a prominent correlation between the Marma Science and Yogic Science, including the different limbs of Ashtanga Yoga. The Yogasanas (Yogic postures) were invented by the ancient sages, through long term research and experience, to stimulate specific Marmas for desired therapeutic benefits; the Marmas are stimulated through the stretching, vibration, rhythmic movement and pressure caused by these practices. The correlation between Marma points and the Shatkarmas (the six cleansing techniques), specific Yogasanas (Yogic postures), Pranayamas, and Bandhas, as well as their corresponding therapeutic benefits have been presented in the article. Ancient sages greatly appreciated the practice of Pratyahara on Marma sites. It is suggested that practicing Dhyana (meditation) on the Marma points can lead to the balancing of the Pranic flow in the body and mind, and thus provide relief in all types of diseases and sufferings. Each of the seven major Chakras, and their corresponding region of the back is a kind of Marma, and these Marmas or Pranic centers of the subtle body energize all the other Marmas or Pranic centers of the physical body.

Thus, significant correlation has been observed between Marma Science and Yogic Science, as well as it has been used extensively in several ancient Indian traditions. The use of Marma Science for therapeutic purposes in these ancient traditions, presents a strong support for the recent attempts at stimulating Marma points for healing applications. The Part-4 of the exploration of the Science of Marma will deal with the foundational elements and current status of Marma Therapy.

\section{Acknowledgements}

Authors would like to acknowledge the subtle guidance of their spiritual guide, Revered Pandit Shriram Sharma Acharya (http://www.awgp.org/about_us/patron_founder). The authors thank the faculty and staff of the Department of Ayurveda and Holistic Health at Dev Sanskriti Vishwavidyalaya, Haridwar for their support in conducting this study.

Compliance with ethical standards: The authors have maintained necessary ethical standards while conducting the study.

Conflict of interest: The authors declare that they have no conflict of interest.

\section{References}

1. Murthy KRS. Susruta samhita. volume I, II, III. Varanasi, Uttar Pradesh, India: Chaukhambha Orientalia; 2008.

2. Gupta KA. Ashtanga hrdyam of vagbhata - vidyotini hindi commentary. Varanasi, Uttar Pradesh, India: Chaukhamba Sanskrit Sansthan; 2005.

3. Brahmavarchas. Pranashakti : ek divya vibhuti (Hindi). Pandit Shriram Sharma Acharya samagra vangamaya. volume 17. 2nd ed. Mathura, Uttar Pradesh, India: Akhand Jyoti Sansthan; 1998.

4. Sharma, S. Kaya me samaya, pranagni ka jakhira (Hindi). Gayatri Tapobhumi, Matura, Uttar Pradesh, India: Yug Nirman Yojana Vistar Trust; 2010.

(http://literature.awgp.org/book/kaya_men_samaya_pranagni_ka_jakheera/v1.1) 
5. Sharma, S. Kaya urja evam usaki chamatkari samarthya (Hindi). Gayatri Tapobhumi, Matura, Uttar Pradesh, India: Yug Nirman Yojana Vistar Trust; 2010.

(http://literature.awgp.org/book/astonishing_power_of_physical_subtle_energy_of_human/v2.2)

6. Sharma, S. The astonishing power of the bio-physical and subtle energies of the human body. Haridwar, India: Shantikunj; 1996.

(http://literature.awgp.org/book/astonishing_power_of_physical_subtle_energy_of_human/v1.1)

7. Joshi SK. Marma science and principles of marma therapy. 1st ed. Haridwar, Uttarakhand, India: Vani Publications; 2010.

8. Joshi SK. Marma chikitsa vigyan (Hindi). Haridwar, Uttarakhand, India: Mrityunjay Mission; 2012.

9. Joshi SK. Marma vigyan evam chikitsa - vaidik chikitsa vigyan (Hindi). Haridwar, Uttarakhand, India: Mrityunjay Mission; 2011.

10. Joshi SK. Marma vigyan evam aushadhopachar dwara chikitsa (Hindi). Haridwar, Uttarakhand, India: Mrityunjay Mission; 2013.

11. Frawley D, Ranade S, Lele A. Ayurveda and marma therapy. Delhi, India: Chaukhamba Sanskrit Pratishthan; 2015.

12. Lad V, Durve A. Marma points of ayurveda. Albuquerque, New Mexico, USA: The Ayurvedic Press; 2015.

13. Schrott E, Raju JR, Schrott S. Marma therapy. (Translated by) Lorys M. London, UK: Singing Dragon; 2016.

14. Phull G, Phull R. Clinical approach to marma chikitsa. New Delhi, India: IP Innovative Publication Pvt. Ltd.; 2019.

15. Phull G, Phull R. Marma vigyana ka chikitsiya upayoga (Hindi). New Delhi, India: IP Innovative Publication Pvt. Ltd.; 2019.

16. Denaud P. Kalaripayat - the martial arts tradition of India. (Translated by) Cain J. Vermont, USA: Destiny Books; 2009.

17. Fox M, Dickens A, Greaves C, Dixon M, James M. Marma therapy for stroke rehabilitation - a pilot study. Journal of Rehabilitation Medicine. 2006;38(4):268-271. DOI: 10.1080/16501970600630820.

(https://www.medicaljournals.se/jrm/content_files/download.php?doi=10.1080/16501970600630820)

18. Kotelevskiy VI. Integrative technology of massage manipulations in physical rehabilitation of students with backbone pathology. Pedagogics, Psychology, Medical-Biological Problems of Physical Training and Sports. 2016;20(3):31-40. http://dx.doi.org/10.15561/18189172.2016.0305.

(https://www.sportpedagogy.org.ua/html/journal/2016-03/html-en/16kviwbp.html)

19. Murota M, Iwawaki Y, Uebaba K, Yamamoto Y, Takishita Y, Harada K, Shibata A, Narumoto J, Fukui K. Physical and psychological effects of head treatment in the supine position using specialized ayurvedabased techniques. The Journal of Alternative and Complementary Medicine. 2016;22(7):526-532. DOI: 10.1089/acm.2015.0388.

(https://www.ncbi.nlm.nih.gov/pmc/articles/PMC4939366/)

20. Sieler R. Kalari and vaittiyacalai: medicine and martial arts intertwined. Asian Medicine. 2012; 7(1): 164 195. https://doi.org/10.1163/15734218-12341247.

(https://brill.com/view/journals/asme/7/1/article-p164_7.xml?language=en)

21. Pathak AK. A study on anatomical concept of kurpara marma and its therapeutic application in grivavata (cervical spondylosis). Thesis for the degree of Doctor of Philosophy (Ph.D.) in Rachana Sharir. Varanasi, Uttar Pradesh, India: Banaras Hindu University; 2015.

(https://shodhganga.inflibnet.ac.in/handle/10603/267960)

22. Dharmesh K. Optimization of individual performance in football by augmenting classical Indian marma therapy, kinesiology-taping and related physical excercises through supportive bio-mechanical parameter. Thesis for the degree of Doctor of Philosophy (Ph.D.) in Physical Education. Tiruchirappalli, Tamil Nadu, India: Bharathidasan University; 2017. (https://shodhganga.inflibnet.ac.in/handle/10603/220290)

23. Bedekar SS. A critical study of gulpha marma in basket ball players with special reference to the role of mash tail along with snehan and swedan as preventive measure. Thesis for the degree of Doctor of Philosophy (Ph.D.) in Ayurved. Pune, Maharashtra, India: Tilak Maharashtra Vidyapeeth; 2007.

(https://shodhganga.inflibnet.ac.in/handle/10603/34851)

24. Rajeshwari PN. A study on rujakara marma and management of viddha laxanas - a clinical study. Dissertation for the degree of Ayurveda Dhanwanthari (M.S.-Shalya Tantra). Bengaluru, Karnataka, India: Rajiv Gandhi University of Health Sciences; 2010. (http://52.172.27.147:8080/jspui/handle/123456789/6831)

25. Vivek J. A comprehensive study on marma \& acupuncture points and evaluation of their therapeutic importance. Dissertation for the degree of Master of Surgery (Ayurveda Dhanvantari) in Shalya Tantra. Bengaluru, Karnataka, India: Rajiv Gandhi University of Health Sciences; 2011.

(http://52.172.27.147:8080/jspui/handle/123456789/4737) 
26. Lele A, Ranade S, Frawley D. Secrets of marma - the lost secrets of ayurveda. Delhi, India: Chaukhamba Sanskrit Pratishthan; 2005.

27. Srivastava VK, Srivastava A. Hand book on marma and panchakarma therapy. Varanasi, Uttar Pradesh, India: Chaukhambha Orientalia; 2019.

28. Pathak AK. Anatomy of marma. (Editor) Awasthi HH. Varanasi, Uttar Pradesh, India: Chaukhambha Orientalia; 2014.

29. Mishra JN. Marma and its management. Varanasi, Uttar Pradesh, India: Chaukhambha Orientalia; 2016.

30. Govindan SV. Massage therapy for diseases of vital areas (marma treatment). New Delhi, India: Abhinav Publications; 2005.

31. Banjare H. Marma - eka adhyayana, acupressure chikitsa paddhati ke vishesha shandarbha me. Dissertation for the degree of Ayurveda Vachaspati (M.D. - Ayurveda) in Rachana Sharira. Raipur, Chhattisgarh, India: Pt. Ravishankar Shukla University; 2009.

(https://shodhganga.inflibnet.ac.in/handle/10603/41426)

32. Ismail SMB. Marmas in ayurveda and their explanation according to modern anatomy. Thesis for the degree of Doctor of Philosophy (Ph.D.) in Ayurveda. Pune, Maharashtra, India: Savitribai Phule Pune University; 1984.

(https://shodhganga.inflibnet.ac.in/handle/10603/145863)

33. Kumar CS. A comprehensive study of marmas with special reference to Ayurvedic and Tamil marma sastras in relation to its applied anatomy. Thesis for the degree of Doctor of Philosophy (Ph.D.) in Ayurveda. Kalady, Kerala, India: Sree Sankaracharya University of Sanskrit; 1999. (https://shodhganga.inflibnet.ac.in/handle/10603/136019)

34. Muley SK. Ayurvediya sanhitokta marma vichara, vaikalyakara marmanche mahatva evam janumarmachya vaikalyakaratvachi uparugna paddhatine punarpadatalani eka abhyasa (Marathi). Thesis for the degree of Doctor of Philosophy (Ph.D. - Ayurveda) in Sharira Rachana. Nanded, Maharashtra, India: Swami Ramanand Teerth Marathwada University; 2007.

(https://shodhganga.inflibnet.ac.in/handle/10603/240135)

35. Parameswaran S. A comprehensive study on sandhi marma shareera w.s.r. to manibandha marma and its injuries (trauma). Dissertation for the degree of Doctor of Medicine (M.D. - Ayurveda) in Shareera Rachana. Bengaluru, Karnataka, India: Rajiv Gandhi University of Health Sciences; 2012. (http://52.172.27.147:8080/jspui/handle/123456789/7127)

36. Vijayanath V. A comprehensive study of marmas in the hasta (hand) w.s.r. to the surface and regional anatomy (cadaver dissection). Dissertation for the degree of Doctor of Medicine (M.D. - Ayurveda) in Shareera Rachana. Bengaluru, Karnataka, India: Rajiv Gandhi University of Health Sciences; 2011. (http://52.172.27.147:8080/jspui/handle/123456789/4578)

37. Vipin PC. A comprehensive study on gulpha sandhi shareera w.s.r. to sports injuries. Dissertation for the degree of Doctor of Medicine (Ayurveda) in Shareera Rachana. Bengaluru, Karnataka, India: Rajiv Gandhi University of Health Sciences; 2011. (http://52.172.27.147:8080/jspui/handle/123456789/4579)

38. Thatte DG. Acupuncture, marma and other asian therapeutic techniques. Varanasi, Uttar Pradesh, India: Chaukhambha Orientalia; 2015.

39. Fedorova M. Die Marmantheorie in der klassischen indischen Medizin (German) (English translation of the title - the marma theory in classical Indian medicine). Thesis for the degree of Doctor of Philosophy (Ph.D.). Munich, Bavaria, Germany: Ludwig-Maximilians-Universität München; 1990. (https://archive.org/details/DieMarmantheorieInDerKlassischenIndischenMedizinFedorova1990/page/n12/mode/2up)

40. Gupta KA. Astanga samgraha (with Hindi commentary) (Hindi). part 1, 2. Varanasi, Uttar Pradesh, India: Chowkhamba Krishnadas Academy; 2016.

41. Murthy KRS. Astanga samgraha of Vagbhata (text, English translation, notes, indices, etc.). volume II sarira, nidana, cikitsita and kalpa sthana. Varanasi, Uttar Pradesh, India: Chaukhambha Orientalia; 2018.

42. Sharma PV. Charaka-samhita (text with English translation). volume I, II. Varanasi, Uttar Pradesh, India: Chaukhambha Orientalia; 2008.

43. Mishra A, Shrivastava V. Exploring the science of marma - an ancient healing technique - part 1: its mention in ancient Indian scriptures. submitted to the Dev Sanskriti Interdisciplinary International Journal (http://dsiij.dsvv.ac.in/). February 2020.

44. Mishra A, Shrivastava V. Exploring the science of marma - an ancient healing technique - part 2: definition and properties of marma. submitted to the Dev Sanskriti Interdisciplinary International Journal (http://dsiij.dsvv.ac.in/). February 2020.

45. Babu SR, Iyer VB. Varmam - an insight into the ancient system of healing. Hosur, Tamil Nadu, India: Varma Kalpa Rejuvenation Center; 2017.

46. Zarrilli PB. When the body becomes all eyes - paradigms, discourses and practices of power in kalarippayattu, a south Indian martial art. New Delhi, India: Oxford University Press; 2001. 
47. Saraswati SS. Mukti ke char sopan - Patanjal yoga sutra ka yogic bhashya (Hindi). Munger, Bihar, India: Yoga Publications Trust; 2004.

48. Sharma S. Gayatri mahavigyan - sanyukta sanskaran (Hindi). revised ed. Mathura, Uttar Pradesh, India: Yug Nirman Yojana Vistar Trust, Gayatri Tapobhumi; 2010.

(http://literature.awgp.org/book/Super_Science_of_Gayatri/v2)

49. The vayu purana - part I. Delhi, India; Motilal Banarsidass; 1960.

(https://archive.org/details/dli.bengal.10689.12977/mode/2up)

50. Singh CS. Koorma puran. Varanasi, Uttar Pradesh, India; Sarvabharatiya Kashirajanyasa; 1972. (https://archive.org/details/in.ernet.dli.2015.407407/mode/2up)

51. Muktibodhananda S. Hatha yoga pradipika - light on hatha yoga. 4th ed. (Guidance of) Saraswati SS. Munger, Bihar, India: Yoga Publications Trust; 2012.

52. Digambarji S, Jha P. Hathapradipika - swatmaram krit (Hindi). 6th ed. Lonavla, Pune, Maharashtra, India: Kaivalyadhama; 2017.

53. Saraswati SN. Gherand samhita - Maharshi Gherand ki yogashiksha par bhashya (Hindi). Munger, Bihar, India: Yoga Publications Trust; 2004.

54. Sharma S, Sharma BD. 108 Upanishad - brahmavidya khand - saral Hindi bhavarth sahit (Hindi). Gayatri Tapobhumi, Mathura, Uttar Pradesh, India: Yug Nirman Yojna Vistar Trust; 2015.

55. Digambarji S, Jha P, Sahay GS. Vasistha samhita (yoga kanda). Lonavla, Pune, Maharashtra, India: Kaivalyadhama; 2017.

56. Saraswati SS. Asana Pranayama Mudra Bandha. Munger, Bihar, India: Yoga Publications Trust; 2006. 